\begin{tabular}{c} 
International Journal of Engineering \& Technology, $7(3)(2018) 1565-1569$ \\
International Journal of Engineering \& Technology \\
SPC \\
Website: $\begin{array}{c}\text { ww. sciencepubco.com/index.php/IJET } \\
\text { doi: } 10.14419 / \text { ijet. } 7 \text { in.13826 } \\
\text { Research paper }\end{array}$ \\
\hline
\end{tabular}

\title{
PV fed Water Pumping System in a Smart Home
}

\author{
Krithiga S. ${ }^{*}$, Partha Sarathi Subudhi² \\ ${ }^{1}$ Associate Professor, School of Electrical Engineering, Vellore Institute of Technology, Chennai Campus \\ ${ }^{2}$ Ph. D. Research Scholar, School of Electrical Engineering, Vellore Institute of Technology, Chennai Campus \\ *Corresponding authorE-mail: s_krithiga@yahoo.com
}

\begin{abstract}
This paper proposes renewable energy based water pumping system in a smart home using a bidirectional DC-DC converter. A backup battery is connected in the system for uninterrupted power supply to the water pump. Depending upon source availability, DC-DC converter acts either in boost mode or in buck mode to supply uninterrupted power to the water pump. Using MATLAB/Simulink software, the proposed system is simulated and its performance is analyzed for various operating conditions and the results are furnished in this paper. A small scale laboratory prototype is fabricated and tested for the designed system. Experimental results acquired from the prototype testing correlates with the simulation results validating the feasibility of the proposed water pumping system.
\end{abstract}

Keywords: Backup Battery; Bidirectional DC-DC Buck Boost Converter; Rooftop PV Array; Zero Voltage Switching Technique.

\section{Introduction}

Advances in home automation technology led researchers to concentrate on smart home system. Smart home systems are reliable, secure, efficient and easily controlled [1]. Uninterrupted supply and easy power flow control with smart power electronic interfaces has made smart home popular [2]. As per the availability of power sources, automated controlling systems utilize power efficiently by controlling the power flow [3, 4]. Invention of fast operating components and smart technologies has made home automation system error free, convenient, reliable and energy efficient compared to conventional controlling system [5].

Energy crises have led researchers to adopt renewable energy sources instead of conventional petroleum products [6]. Renewable energy sources like geothermal energy, wind energy, wave energy and solar energy are used from ages. Among all the renewable energy sources available, photovoltaic (PV) power is accepted by most of the researchers for its easily availability, no poisonous byproduct, easy accessibility, long life time and high efficiency [7]. Net energy taken from the utility grid by the smart home system reduces by integrating PV array. Integration of PV array generated power with smart home system creates a benchmark in smart home research area.

Utilization of PV generated power for water pumping system in a smart home is a promising area of PV application [8]. Among all the dc loads available in a smart home system, water pumping system is commonly used and integration of PV array with water pumping adds advantage to the water pumping system. With change in irradiation and temperature, PV array output power changes [9]. Due to intermittent nature of solar power, a backup battery is connected with the water pumping system for providing uninterrupted power supply [10]. This backup battery operates the main system during low power generation from the PV array [11]. When surplus power is generated, the battery gets charged by the power generated from PV array. For integrating the PV array with smart home system, a bidirectional buck boost converter is connected as a power electronic interface [12].

This paper proposes a smart home system employing a DC-DC converter for feeding the PV array generated power to the water pump. A backup battery is also used in the system to supply the uninterrupted power to the water pump under low irradiation conditions. When excess PV array power is available, backup battery is charged by PV array.

Proposed solar water pumping system mainly consists of PV array, bidirectional buck boost converter, controller, backup battery and water pump. With the availability of solar power, the controller operates the switches of the DC-DC converter either in buck mode or in boost mode for controlling power flow direction. Also a switch is connected in series with the PV array to isolate the system from the PV array during low irradiation condition. At that time, the backup battery acts as a source to the water pumping system. Detailed description of the proposed system is explained in the following section.

\section{Proposed water pumping system}

The proposed water pumping system consists of PV array, bidirectional DC-DC converter, controller, backup battery and water pump is depicted in Fig.1. The PV array is considered to be a roof top PV array, which generates dc power from solar irradiation. The generated dc power is used to operate the water pump directly as only the speed of the water pump is going to vary depending on irradiation. In smart home, for providing uninterrupted power supply to the water pumping system, a backup battery is also connected which provides power to the proposed system in the absence of solar power. The backup battery is interfaced with the system by using a bidirectional DC-DC buck boost converter. Details regarding different components used in the proposed system are provided in the following sub sections. 


\subsection{Photovoltaic array}

PV array converts solar energy into dc power. With the change in solar irradiance, the output power of the PV array varies. A roof top PV array is considered as the primary source of power for this proposed solar water pumping system. A switch, $\mathrm{S}_{1}$ is connected in series with the PV array to isolate it from the proposed system during low irradiance condition and the power to water pumping system is supplied by the backup battery.

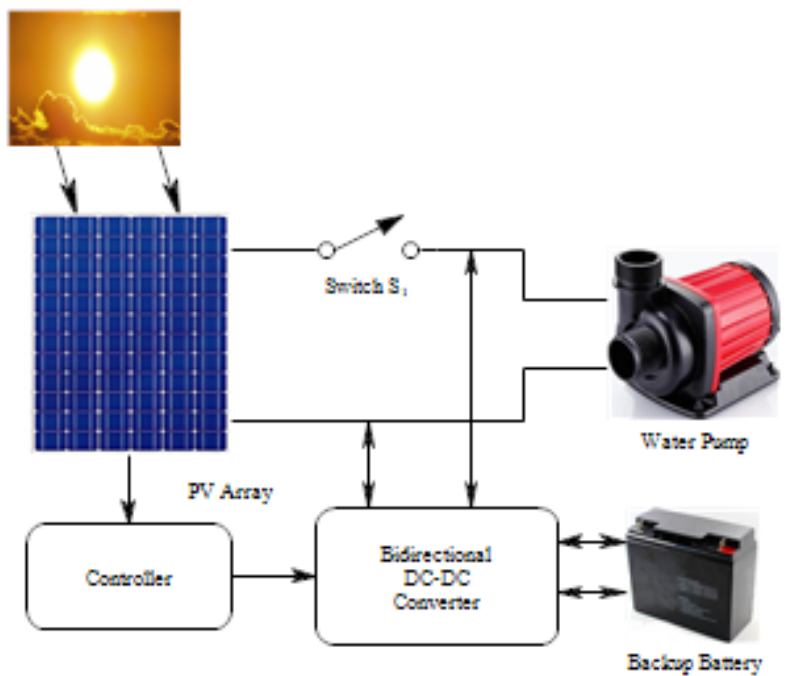

Fig. 1: Block Diagram of the Proposed Water Pumping System.

\subsection{Bidirectional buck boost converter}

The backup battery is connected to the solar water pumping system using a bidirectional DC-DC converter [13]. Backup battery voltage is considered to be lesser than the water pump operating voltage. Therefore, the converter operates in boost mode for driving the water pump.

When the PV array generates surplus power, the solar pump uses the required amount of the generated power from the PV array and the remaining PV power is fed to the backup battery. During battery charging condition, the bidirectional converter step down the generated PV array voltage to the battery terminal voltage in buck mode. During low solar irradiance, the generated PV power is insufficient to operate the water pump. Thus, in this mode, PV array is isolated from the system using the switch, $\mathrm{S}_{1}$ and the water pump is operated using the stored energy from the backup battery. The converter step up the battery voltage to match with the water pump terminal voltage in boost mode.

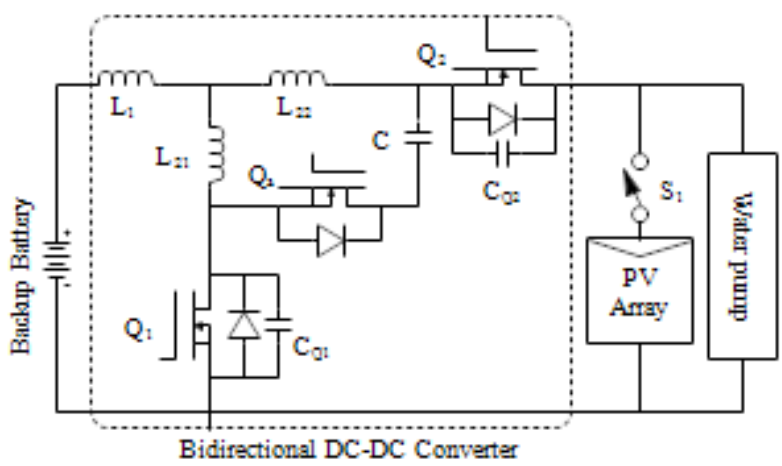

Fig. 2: Schematic Diagram of the Proposed Water Pumping System.

Fig.2 shows the schematic diagram of the proposed water pumping system employing bidirectional converter. This converter uses one auxiliary switch, $\mathrm{Q}_{\mathrm{a}}$ and two main switches $\mathrm{Q}_{1}$ and $\mathrm{Q}_{2}$. The switches, $\mathrm{Q}_{1}$ and $\mathrm{Q}_{2}$ operate with zero voltage switching (ZVS) technique. Detailed explanation of different modes of operation of bidirectional DC-DC converter is given in literature [13].

\subsection{Controller}

The controller used in this proposed system regulates the operation of switches in the bidirectional DC-DC converter. During low irradiation conditions, PV array current is sensed and if its value is less than the reference value, switch, $S_{1}$ is turned off isolating the PV array from the system and vice versa during high irradiation, connecting the PV array to the system by turning on the switch, $\mathrm{S}_{1}$. During low irradiation conditions, the DC-DC bidirectional converter operates in boost mode for feeding the power from the backup battery to water pump with switch, $\mathrm{Q}_{2}$ turned off. Battery voltage, $\mathrm{V}_{\mathrm{b}}$ is boosted to the water pump terminal voltage, $\mathrm{V}_{\mathrm{L}}$ and is fed to the water pump. The gate pulse for switch, $\mathrm{Q}_{1}$ is generated with the duty cycle as per equation (1).

$V_{L}=\frac{V_{b}}{1-d_{Q 1}}$

Where, $\mathrm{d}_{\mathrm{Q} 1}=$ duty cycle of the gate pulse, $\mathrm{V}_{\mathrm{gQ1}}$ during boost mode

During higher irradiation conditions, the PV array generated power is used to operate the water pump and the excess power is fed to the backup battery simultaneously. Hence, in this mode, bidirectional DC-DC converter operates in buck mode for feeding power from PV array to backup battery with switch, $\mathrm{Q}_{1}$ turned off. The gate pulse for switch $\mathrm{Q}_{2}$ is generated with duty cycle calculated as per equation (2).

$V_{b}=d_{Q 2} * V_{P V}$

Where, $\mathrm{d}_{\mathrm{Q} 2}=$ duty cycle of the gate pulse, $\mathrm{V}_{\mathrm{gQ} 2}$ during buck mode.

In both modes, gate pulse for the auxiliary switch, $\mathrm{Q}_{\mathrm{a}}$ is generated with duty cycle of $10 \%$ for enabling the zero voltage switching (ZVS) conditions in order to avoid the switching losses [13]. The proposed system is simulated in MATLAB/Simulink software and the results are presented in the following section.

\section{Simulation studies and results}

Fig. 3 shows the simulation diagram of proposed water pumping system. PV array is modelled using the classical equations of solar cells [14]. The PV array comprises of two series connected PV panels with the per panel open circuit voltage and short circuit current of $35.07 \mathrm{~V} \& 6.48$ A respectively.

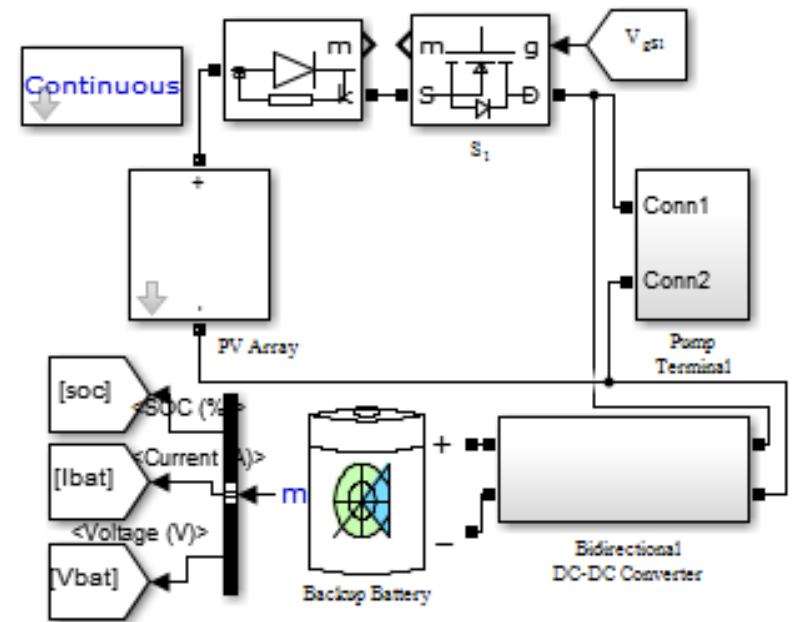

Fig. 3: Simulation Diagram of the Proposed Water Pumping System.

A lead acid battery of nominal voltage $36 \mathrm{~V} \&$ capacity $100 \mathrm{Ah}$ is considered as the backup battery in the proposed system. The initial state of charge of the battery is considered as $50 \%$. The battery model available in the library of MATLAB/Simulink is used for simulation. 


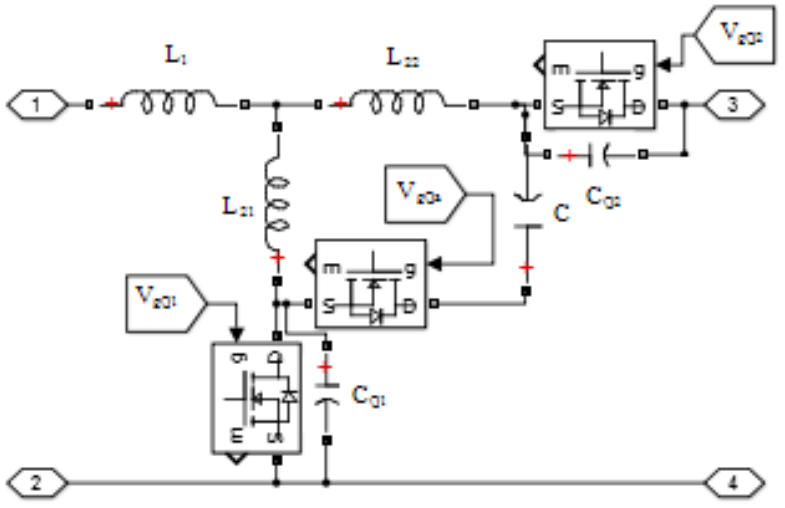

Fig. 4: Simulation Diagram of Bidirectional DC-DC Converter.

Simulation model of the bidirectional buck boost converter is constructed using inductors $\mathrm{L}_{1}, \mathrm{~L}_{21}$ and $\mathrm{L}_{22}$, capacitor $\mathrm{C}$, and MOSFET switches $\mathrm{Q}_{1}, \mathrm{Q}_{\mathrm{a}} \& \mathrm{Q}_{2}$ as shown in Fig.4. The value of inductor, $\mathrm{L}_{1}$ is $500 \mu \mathrm{H}$ and two resonant inductors, $\mathrm{L}_{21} \& \mathrm{~L}_{22}$ is $1.44 \mu \mathrm{H}$ each and the capacitor is $44 \mathrm{nF}$ which are designed as per formulae presented in literature [13].

The controller is constructed using pulse generators and selector switch from Simulink library as shown in Fig.5. In boost mode, the PV array is isolated from the system using the switch $\mathrm{S}_{1}$. The stored energy in the backup battery operates the water pump. In this mode, switches $\mathrm{Q}_{1}$ and $\mathrm{Q}_{\mathrm{a}}$ operates with a duty cycle of $40 \%$ and $10 \%$ respectively and switch, $\mathrm{Q}_{2}$ remains in off state. Gate pulses for switches during boost mode are shown in Fig.6 (a). In buck mode, the PV array is connected to the proposed water pumping system by closing the switch, $\mathrm{S}_{1}$. During this mode, switches, $\mathrm{Q}_{2}$ and $\mathrm{Q}_{\mathrm{a}}$ operate with a duty cycle of $60 \%$ and $10 \%$ respectively and switch $\mathrm{Q}_{1}$ remains in off state as shown in Fig.6 (b).

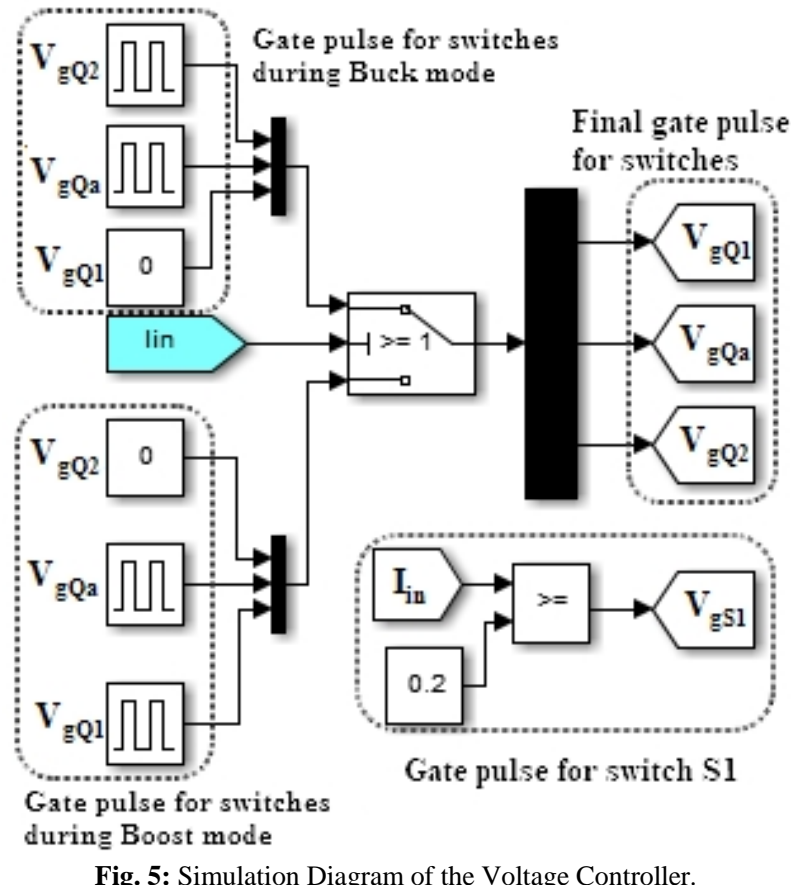

In order to observe the dynamic response of the system, it is operated in boost mode from $0 \mathrm{~s}$ to $0.3 \mathrm{~s}$ and in buck mode from $0.3 \mathrm{~s}$ to $0.7 \mathrm{~s}$ and the simulation results are shown in Fig.7. During boost mode, PV array is isolated from the system by turning off the switch, $\mathrm{S}_{1}$ which is indicated by the $\mathrm{PV}$ array voltage, $\mathrm{V}_{\mathrm{PV}}$ being equal to its open circuit voltage, $\mathrm{V}_{\mathrm{OC}}$ of $70 \mathrm{~V}$ and PV array current, Ipv being equal to zero as shown in Fig.7 (a) \& 7(b) respectively.
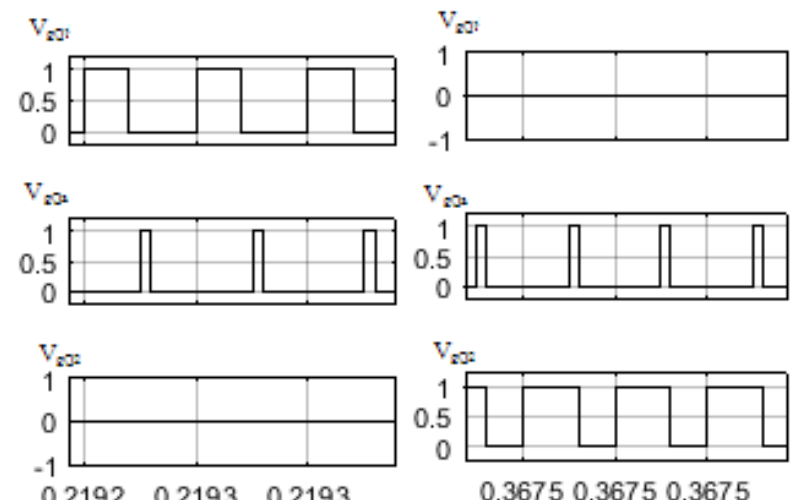

$\begin{array}{lll}0.2192 & 0.2193 & 0.2193\end{array}$

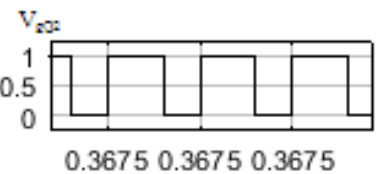

Fig. 6: Gate Pulses for Switches during (a) Boost Mode, (b) Buck Mode.

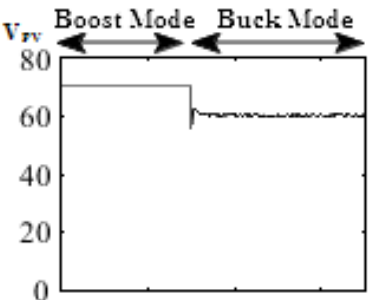

(a)

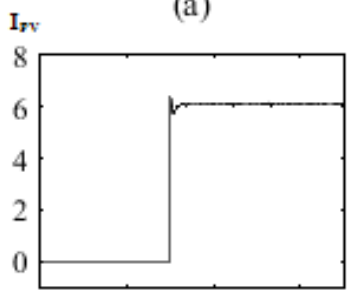

$\mathrm{V}$ 。

(b)

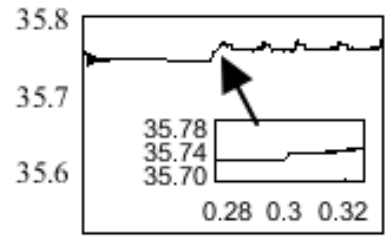

(c)

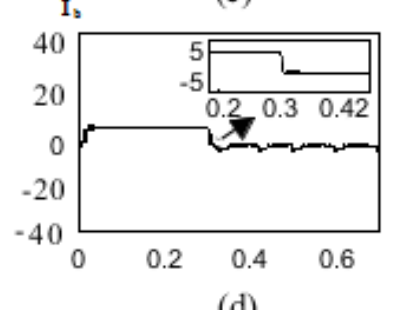

(d)

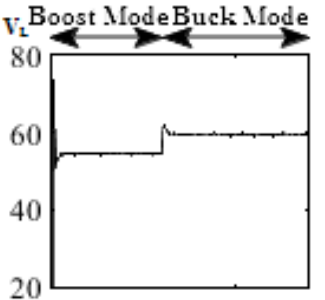

(e)

$\mathrm{I}_{2}$

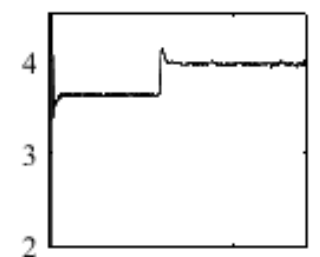

(f)

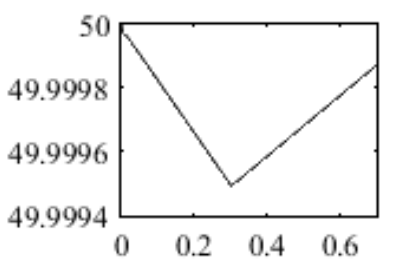

$(\mathrm{g})$
Time

Fig. 7: Simulation Waveform of Proposed Water Pumping System (a) PV Array Voltage (b) PV Array Current (c) Backup Battery Voltage (d) Backup Battery Current (e) Water Pump Terminal Voltage (f) Water Pump Terminal Current (g) Battery SOC.

Fig.7 (c) \& 7 (e) shows that the battery voltage, $V_{b}$ of $35.7 \mathrm{~V}$ is increased to $53.3 \mathrm{~V}$ to drive the water pump and their corresponding currents are of $5.4 \mathrm{~A}$ and $3.6 \mathrm{~A}$ respectively are shown in Fig.7 (d) \& 7 (f). Also decrease in battery SOC shown in Fig.7 (g) indicates the discharging of battery in this mode.

During buck mode, switch, $S_{1}$ is on and PV array power of $366 \mathrm{~W}$ generated at an irradiation of $770 \mathrm{~W} / \mathrm{m}^{2}$ is connected to the system. In this mode, approximately $243 \mathrm{~W}$ of PV power is utilized to drive the water pump and the remaining $110 \mathrm{~W}$ power is used to charge the backup battery through the bidirectional converter with $90 \%$ system efficiency. Fig.7 (a) \& 7(c) shows that the PV array voltage, $\mathrm{VPV}_{\mathrm{PV}}$ of $62.2 \mathrm{~V}$ is step down to $35.7 \mathrm{~V}$ by the bidirectional DC-DC converter to charge the battery in this mode. Also, the 
increase in battery SOC and negative battery current of 3.08 A indicates the charging of battery as shown in Fig.7 (g) \& 7(d). A small scale laboratory prototype is designed and fabricated to justify the system behaviour and observed results are presented in the following section.

\section{Experimental investigation of the proposed system}

A hardware prototype of the bidirectional converter is fabricated in the laboratory using the components specified in Table 1 and tested in boost and buck mode separately and the results obtained in experimentation are shown in this section. Fig.8 shows the experimental test bench of the proposed system.

Table 1: Components Used for Hardware Prototype Fabrication

\begin{tabular}{lll}
\hline S1. No. & Components & Specification \\
\hline 1 & MOSFET, IRF 250N & $100 \mathrm{~V}, 30 \mathrm{~A}$ \\
2 & Driver, TLP 250 & $15 \mathrm{~V}, 0.01 \mathrm{~A}$ \\
3 & Capacitor & $44 \mathrm{nF}, 100 \mathrm{~V}$ \\
4 & Inductor & $500 \mu \mathrm{H}, 10 \mathrm{~A}$ \\
5 & Inductor & $1.44 \mu \mathrm{H}, 10 \mathrm{~A}$ \\
6 & Microcontroller, p18f45k20 & - \\
\hline
\end{tabular}
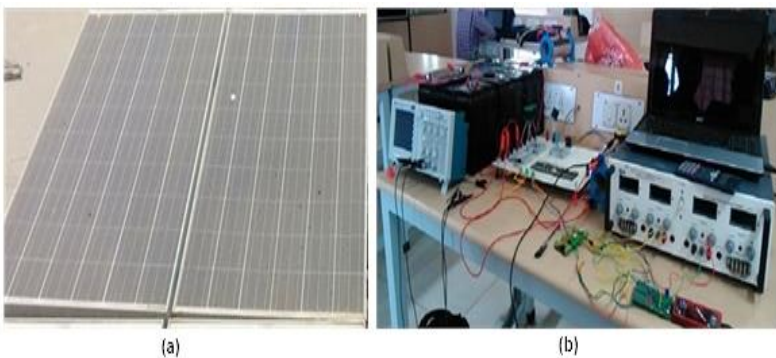

Fig. 8: Photograph of (a) PV Array and (b) Experimental Test Bench.

In boost mode, conventional dc supply of $44 \mathrm{~W}$ is connected in battery side to drive approximately $40 \mathrm{~W}$ resistive load connected at the water pump terminal/high voltage side of the bidirectional DC-DC converter and the gate pulses of $50 \mathrm{kHz}$ switching frequency is provided to switches $\mathrm{Q}_{1}$ and $\mathrm{Q}_{\mathrm{a}}$ with the duty cycle of $47 \%$ \& $10 \%$ respectively as shown in Fig.9. The input voltage, $\mathrm{V}_{\mathrm{b}}$ of $32.1 \mathrm{~V}$ is boosted to $58.4 \mathrm{~V}$ to drive the load as shown in Fig.10 (a) \& 10 (b). The waveforms of input \& output voltage and current in boost mode is shown in Fig.10.

In buck mode, $54 \mathrm{~W}$ of PV array power is used to drive the load of approximately $28 \mathrm{~W}$ connected in the water pump terminal and the remaining $26 \mathrm{~W}$ of $\mathrm{PV}$ array power is fed to the another load of $24 \mathrm{~W}$ through the bidirectional DC-DC converter. The switches, $\mathrm{Q}_{2} \& \mathrm{Q}_{\mathrm{a}}$ are provided with the $50 \mathrm{kHz}$ gate pulses of duty cycle $37.1 \%$ \& $9.8 \%$ respectively as shown in Fig.11. The waveforms of input \& output voltage and current in this mode are provided in Fig. $12 \& 13$ and it depicts that, PV array voltage of $60.5 \mathrm{~V}$ is fed directly to load connected in water pump terminal

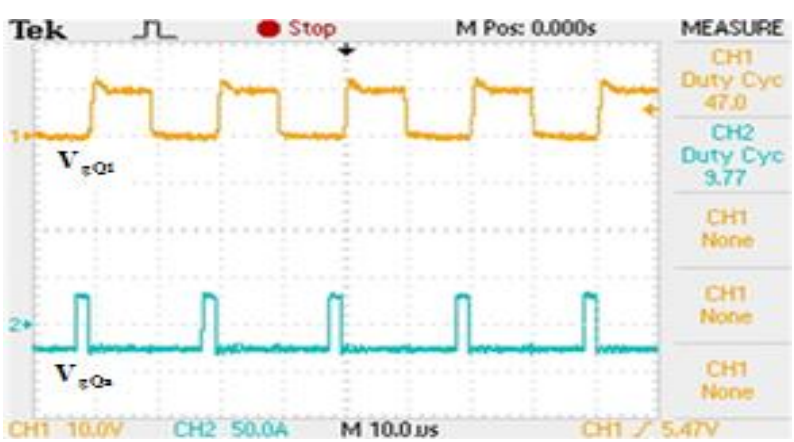

Fig. 9: Waveforms of Gate Pulses for the Switches $Q_{1}$ and $Q_{a}$ in Boost Mode.

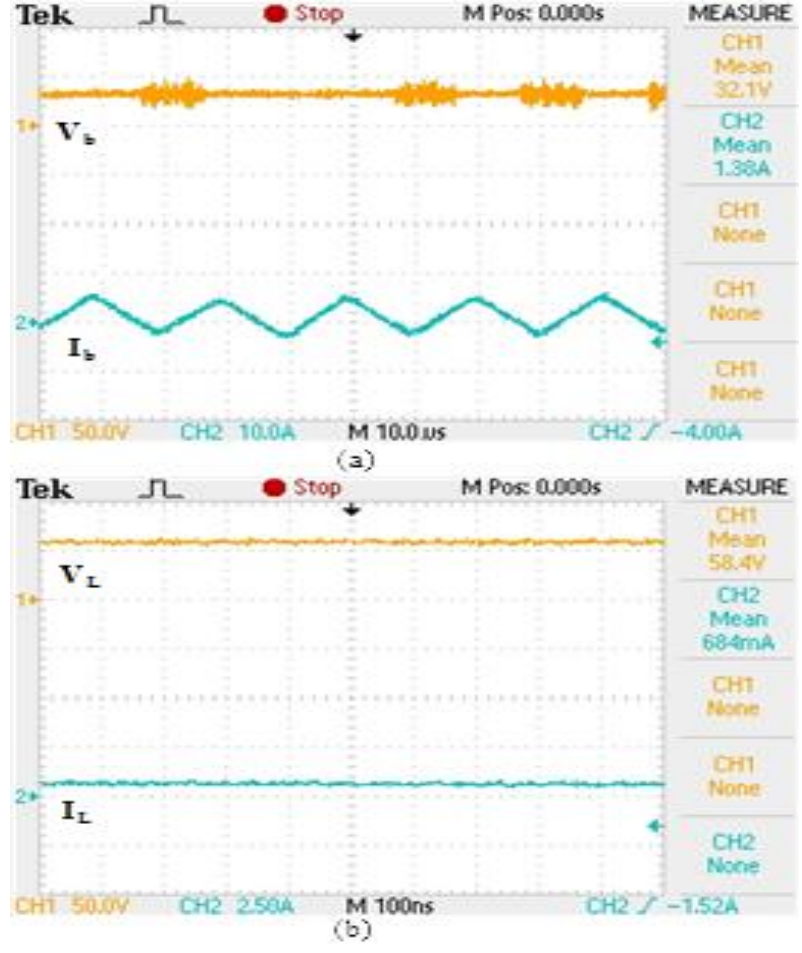

Fig. 10: Waveforms of (a) Battery Side Terminal Voltage \& Current and (b) Water Pump Terminal Voltage \& Current in Boost Mode.

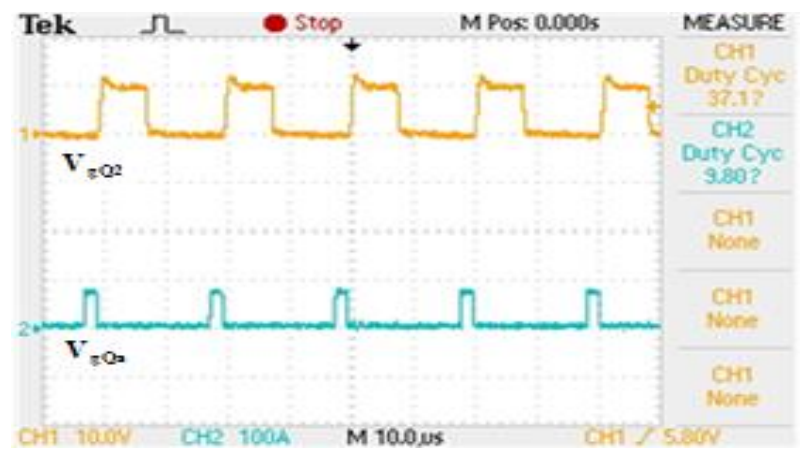

Fig. 11: Waveforms of Gate Pulses for Switches $Q_{2} \& Q_{a}$ in Buck Mode.
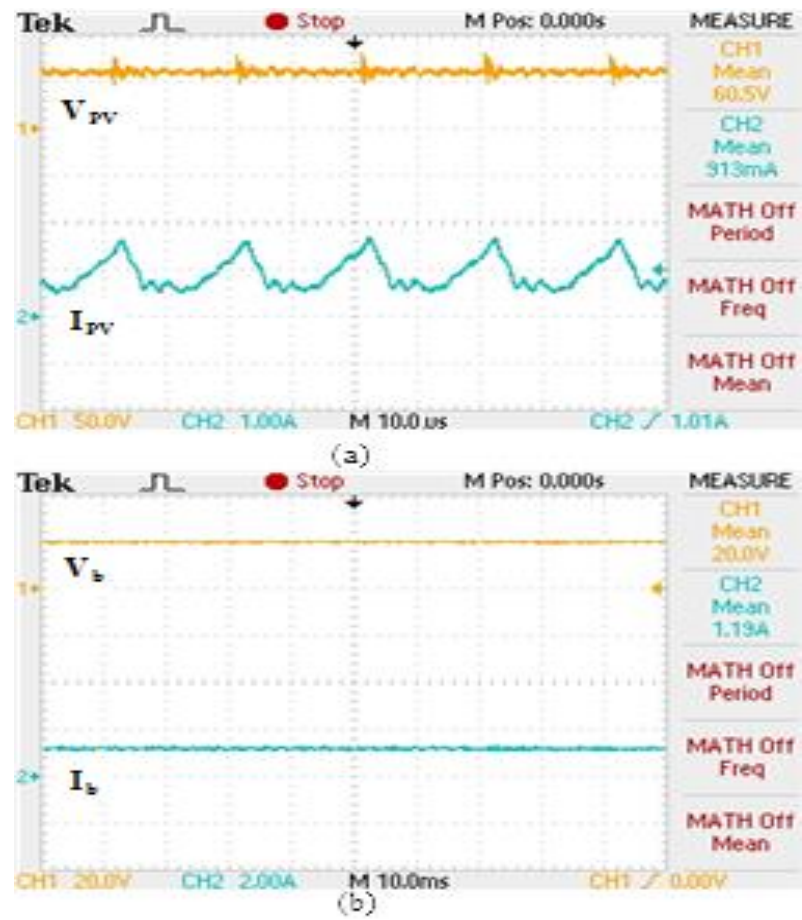

Fig. 12: Waveforms of (a) PV Array Voltage \& Current, (b) Input Voltage $\&$ Input Current of Bidirectional Converter in Buck Mode. 
Also, the PV array voltage of $60.5 \mathrm{~V}$ is bucked to $20 \mathrm{~V}$ and fed to the load in the battery terminal. From the experimentation results, efficiency of the bidirectional DC-DC converter is found to be approximately $90 \%$ \& $95 \%$ in boost mode and buck mode respectively. From the simulation and experimentation of the proposed system, it is evident that, the results are well correlated with each other.

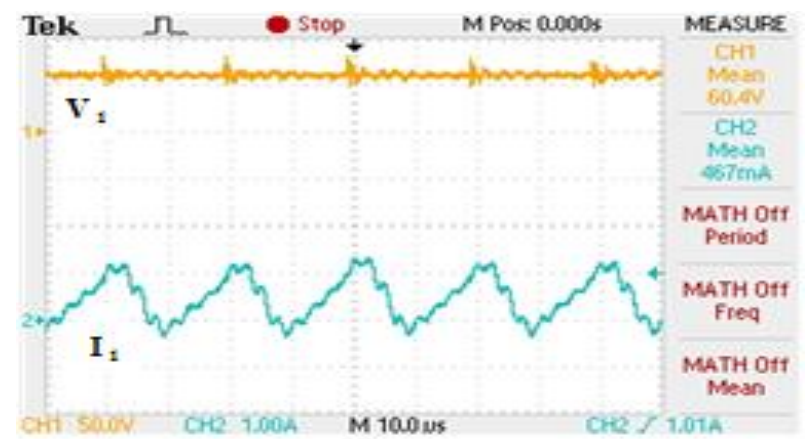

(3)

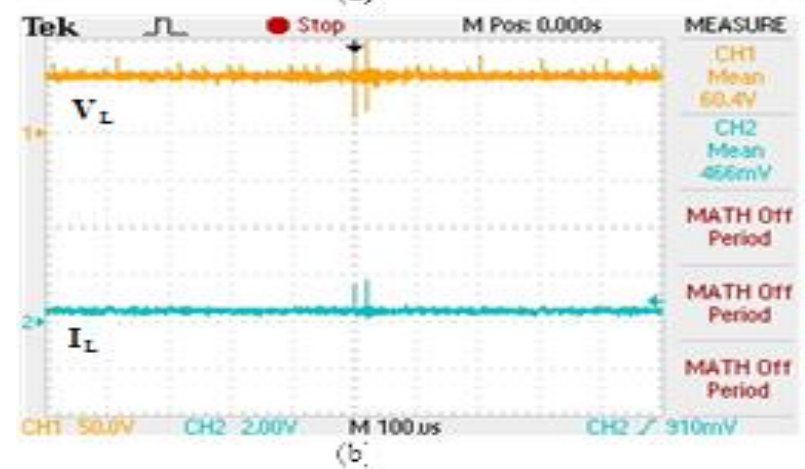

Fig. 13: Waveforms of (a) Voltage and Current at Battery Terminal (b) Voltage \& Current at Water Pump Terminal in Buck Mode.

\section{Conclusion}

A PV fed water pumping system employing bidirectional buck boost converter with backup battery facility in a smart home is proposed in this paper. Irrespective of change in PV array power, the water pump is supplied with the uninterrupted power either by PV array or backup battery. The backup battery gets charged by the surplus PV array power using bidirectional converter operating in buck mode and discharges in boost mode to drive the load during low irradiance condition. The proposed system is a closed loop system which responds automatically to the variation in irradiation condition of PV array. Thus, autonomy operation of this system makes it smarter compared to the existing conventional systems. Simulation of the proposed system is carried out in MATLAB/Simulink software. The experimental prototype of the converter is fabricated and investigated in laboratory. Similarity of hardware result with the simulation result validates the efficacy of the proposed system.

\section{Acknowledgement}

The authors would like to thank Mr. Kummari Paramesh, M. Tech. student, School of Electrical Engineering, Vellore Institute of Technology, Chennai, India for his contributions in the simulation \& experimental investigation of the proposed system.

\section{References}

[1] G. Lobaccaro, S. Carlucci, and E. Löfström, "A Review of Systems and Technologies for Smart Homes and Smart Grids," Energies, vol. 9, no. 5, p. 348, May 2016. “available online: http://www.mdpi.com/1996-1073/9/5/348 ", https://doi.org/10.3390/en9050348

[2] D. K.V.DayaSagar, P. Sai Durga, G. Kavya, K. Sri Sravya, and K. Krishna Veni, "Mobile based home mechanization framework using IoT for smart cities," Int. J. Eng. Technol., vol. 7, no. 2.7, p. 266,Mar.2018.“availableonline:https://www.sciencepubco.com/ind ex.php/ijet/article/view/10594".

[3] P. Gopi Krishna, K. Sreenivasa Ravi, R. Trinadh, K. Chandra Sekhar, and V. Ranjit Kumar, "Design and development of smart energy meter for effective use of electricity in IoT applications," Int. J. Eng. Technol., vol. 7, no. 2.8, p. 115, Mar. 2018. "available online: https://www.sciencepubco.com/index.php/ijet/article/view/10342".

[4] K. Naga Siva Rao, D. K. Sreenivasa Ravi, and P. Gopi Krishna, "Occupancy based home automation system," Int. J. Eng. Technol., vol. 7, no. 2.7, p. 394, Mar. 2018. "available online: https://www.sciencepubco.com/index.php/ijet/article/view/10750".

[5] S. Marrapu, S. Sanakkayala, A. kumar Vempalli, and S. K. Jayavarapu, "Smart home based security system for door access control using smart phone,” Int. J. Eng. Technol., vol. 7, no. 1, p. 249, Mar. 2018."availableonlin: https://www.sciencepubco.com/index.php/ijet/article/view/9247",

[6] H. O. Alwan and N. M. Farhan, "Load restoration methodology considering renewable energies and combined heat and power systems," Int. J. Eng. Technol., vol. 7, no. 2.6, p. 130, Mar. 2018. "avaibleonline:

https://www.sciencepubco.com/index.php/ijet/article/view/10138 ".

[7] B. Sushil Kumar, S. Krithiga, and P. Sarathi Subudhi, "Wireless Electric Vehicle Battery Charging System using PV Array," Indian J. Sci. Technol., vol. 9, no. 36, pp. 1-5, Sep. 2016. "available online: http://www.indjst.org/index.php/indjst/article/view/98147”. https://doi.org/10.17485/ijst/2016/v9i36/98147.

[8] W. H. Kazeza, L. J. Ngoma, and S. P. Chowdhury, "Optimization of a solar based water pumping system using a high step up inverter," in International Conference on Renewable Power Generation (RPG2015),2015.“availableonline:http://digitallibrary.theiet.org/co ntent/conferences/10.1049/cp.2015.0514".

[9] S. Salcedo-Sanz, C. Casanova-Mateo, A. Pastor-Sánchez, and M Sánchez-Girón, "Daily global solar radiation prediction based on a hybrid Coral Reefs Optimization - Extreme Learning Machine approach," Sol. Energy, vol. 105, pp. 91-98, Jul. 2014. "available online:http://linkinghub.elsevier.com/retrieve/pii/S0038092X14001 947 ". https://doi.org/10.1016/j.solener.2014.04.009.

[10] S. Sivakumar and K. S. Naidu, "Modelling and implementation of Mppt ( Inc ) algorithm for Pv water pump applications using Matlab," Int. J. Eng. Technol., vol. 7, no. 1.7, pp. 165-168, 2018. "avaibleonline:https://www.sciencepubco.com/index.php/ijet/article /view/10643".

[11] M. Jain, M. Daniele, and P. K. Jain, "A bidirectional DC-DC converter topology for low power application," IEEE Trans. Power Electron., vol. 15 , no. 4, pp. 595-606, Jul. 2000. "available online: http://ieeexplore.ieee.org/document/849029/", https://doi.org/10.1109/63.849029.

[12] R. Elavarasu and C. Christober Asir Rajan, "Closed loop Fuzzy Logic Controlled Interleaved DC-to-DC converter Fed DC Drive System,” Int. J. Eng. Technol., vol. 7, no. 2.24, p. 397, Apr. 2018 "avaibleonline:https://www.sciencepubco.com/index.php/ijet/article /view/12120".

[13] P. Das, B. Laan, S. a. Mousavi, and G. Moschopoulos, "A Nonisolated Bidirectional ZVS-PWM Active Clamped DC-DC Converter," IEEE Trans. Power Electron., vol. 24, no. 2, pp. 553-558, Feb. 2009“availableonline:http://ieeexplore.ieee.org/document/4745749/

[14] N. G. A. Gounden and S. Krithiga, "Power electronic configuration for the operation of PV system in combined grid-connected and stand-alone modes," IET Power Electron., vol. 7, no. 3, pp. 640647, Mar. 2014. "available online: http://digitallibrary.theiet.org/content/journals/10.1049/ietpel.2013.0107". 